\title{
The Impact of Individualized Homework Assignment on Iranian Intermediate EFL Learners' Motivation
}

\author{
Hamed Abbasi Mojdehi \\ Department of English Language, Rasht Branch, Islamic Azad University, Rasht, Iran \\ Davood Taghipour Bazargani \\ Department of English Language, Rasht Branch, Islamic Azad University, Rasht, Iran
}

\begin{abstract}
This study was designed to investigate the effectiveness of applying individualized homework assignments on Iranian intermediate level EFL learners' motivation. To achieve this objective, 60 learners in the 16-21 age range who were studying at two private language institutes in Rasht, Iran, were selected from 122 participants based on their performance on QPT. The participants were randomly assigned to experimental and control groups. A pretest piloted before with an accepted reliability index was administered to both groups. Next, the experimental group received the treatment for 20 sessions (doing homework materials specifically designed based on each learner's interests and preferred learning style). Meanwhile, the control group received a placebo which was the use of exercises in the workbook of the coursebook American English File 3 (Second Edition) as homework assignments. The posttest of motivation was then administered to both groups. The results showed significantly higher scores on motivation test for experimental group at the end of the course. Based on the findings of this study, language teachers can utilize individualized homework assignments to motivate their learners for doing their homework more willingly.
\end{abstract}

Index Terms — individual differences, individualized homework, learning styles, learners' interests, motivation

\section{INTRODUCTION}

In the first half of the $20^{\text {th }}$ century, under the heavy shadows of structuralism and behaviorism, the dominant idea in applied linguistics was that making changes in methods of teaching or the teacher's skills will be enough for creating a better environment for learning and eventually make learners more successful. In other words, focus of attention mostly was on language itself, not on persons who are learning that language. Today it has been generally accepted that teaching does not just depend on teacher's knowledge, or on the language system itself. There are some factors and variables that depend on learners' genetic predispositions or their family situation, or in another word, 'environmental, social, and affective factors'. In a post-method world, a pedagogy system hardly can be effective if it does not acknowledge the learners' feelings and their unique characteristics. As Kumaravadivelu (2006) emphasized, nowadays methods, mostly learner-centered methods, "are principally concerned with learner needs, wants and situations" (p. 91). It is understandable why a teaching method which acknowledges each learner's unique personality and his/her personal interests could be more effective; If the learners feel that the learning process is more in accordance with their characteristics and their personality and comprises activities and tasks in favor of their special interests, they would probably become motivated. The importance of knowing about learners' situations and wants and different characteristics, therefore, is immense. Most teachers gradually understand these differences in their learners during the course and sometimes they don't know about most of them even by the end of the course. But nevertheless, good teachers know that each and every one of their students are unique.

Individual differences, or as Robinson (2003) classified them, affective factors and cognitive factors, are always with learners. This includes all the time they spend outside the classroom or school, the time which they spend with their friends and families, the time they do extracurricular activities, and the time they spend on their homework. Cooper (1989) in his influential study, achieved interesting results about homework. He suggested that Individual differences among students play a large role because homework occurs in situations that give students more discretion concerning when and how (and, indeed, whether) to complete an assignment. Therefore, for designing material for homework, as well as for in-class activities, material developers or teachers should pay attention to these affective and cognitive factors. This implies that designing learner-based tasks or activities specifically for homework could make learners motivated to do their homework and thus become more effective learners.

Aside from considering learners' personality and their interests in designing materials, there is yet another ID factor which could help material developers and teachers. Lots of researchers studied the role of learning styles and cognitive styles in second language learning and acquisition (e.g. Dunn, Debello, Brennan, Krimsky, \& Murrain, 1981; Ehrman, 
1996; Keefe, 1979). The results of these empirical studies imply that a harmony between learners' learning style and the teaching method might help them to be more successful in language learning.

The results of another important study by Wong and Nunan (2011) showed that $40 \%$ of more effective learners reported spending between 1 and 5 hours a week on English out of class, as completing tasks, doing activities, or doing homework. Twenty-nine per cent of more effective learners spent their time on English in places other than the class more than 10 hours a week. In case of less effective learners, none of them spent more than 10 hours a week out of class, while about $70 \%$ of them spent less than 1 hour a week on English out of class. Of course, they brought up the important question about the direction of influence; Do effective learners spend more time on homework and practicing out of class because they like it and they are successful at it, or is it the other way around, they are good at it exactly because they spend more time out of class on practicing English? Whatever the answer to this question is, one thing is certain; the effective learners usually spend more time on homework and practicing.

Giving homework assignments to the learners will keep them engaged with their learning and reinforce it, and here the problem reveals itself. Learners usually lack genuine interest and enthusiasm for doing homework. Gardner and MacIntyre (1992) proposed that individual differences act in both formal and informal language learning situations. Formal situations refer primarily to classroom settings where direct language instruction is provided. Informal situations, on the other hand, refer to language acquisition contexts where learning is incidental to some other activity. In such contexts, the exposure to the language can be considered voluntary. Once an individual has decided to enter informal situations, both cognitive and affective variables will operate (cited in MacIntyre, 1999, p. 49). Homework, or takehome assignment, as the name suggest, will most likely be taken place in informal situations, so individual differences could affect in it even more.

We know that most of the learners hate doing homework, so can we somehow make learners more enthusiastic about it? Does acknowledging learners' individual characteristics and interests help teachers to modify their teaching methods and classroom activities, and eventually make them more interested in learning? Although family could play the role of authority, but not as effective as the real thing, because the family may lack the teaching skills and the knowledge required for necessary help. If the learners become personally interested and motivated, they will become more selfregulated and they would self-correct.

Tomlinson (2013) used the terms 'Humanization', 'Personalization', and 'Localization' repeatedly and emphasized on the important role of these processes in adapting and developing modern materials for language teaching. Admittedly developing materials for every one of the activities and tasks in the classroom is a very hard and complicated job, but doing it just for homework assignment could be a practical and manageable task. The term 'Individualized Homework' is being coined to refer to such homework assignment. This study sought to provide a framework for designing or adapting the material for homework assignment based on the individuals' a) Preferred learning style, and b) Personal interests and passions or 'wants'. In addition, it tries to find out if this kind of homework designing can eventually make the learners more motivated for learning language.

The following null hypothesis were formulated:

$\mathbf{H}_{\mathbf{0}}$ : Using individualized homework does not have any significant effect on Iranian intermediate EFL learners' motivation.

\section{LITERATURE REVIEW}

\section{A. Individual Differences and Language Learning}

Dornyei (2005) gives a history of individual differences and explains that Sir Francis Galton (1822-1911) was the first to study individual differences (IDs) scientifically and consequently put individual difference factors on the research agenda. 'Binet-Simon Intelligence Skill' which was introduced in 1905, Ann Anastasi's (1958) book named Differencial Psychology which was somehow a summary of individual differences studies in psychology, Carrol and Sapon's (1959) practical aptitude test (MLAT) which aimed to predict the learners' degree of success in language learning, and Gardner and Lambert's (1959) study on motivation, were some of the important studies in this field. These studies and the extensive amount of literature about them which were published in the next decades made other researchers realize that the learners themselves are important parties in the learning process, so the attention to the learners and their individual characteristics gradually increased. Lots of literature about different factors of individual differences and the relationship between them and second language learning and their implications for language learning stake-holders were published recently (Birch \& Hayward, 1994; De Raad, 2000; Dornyei, 2005; Dornyei \& Skehan, 2003; Ehrman, Leaver, \& Oxford, 2003; Ellis, 2008; Eysenck, 1994; Robinson, 2002; Skehan, 1989; Ushioda, 2013; Wong \& Nunan, 2011).

Now, what does 'Individual Difference' exactly mean? Dornyei (2005) defines individual differences as "enduring personal characteristics that are assumed to apply to everybody and on which people differ by degree" (p. 4). Individual differences comprises factors like motivation, intelligence, aptitude, learning style, anxiety, creativity, etc. Skehan (1989), Robinson (2002, 2003), Dornyei (2005), and Ellis (2008), each proposed their own list of the most important ID factors. This study, mostly deals with two important individual differences; learners' 'learning style' and 'motivation'.

The concept of 'learning style', as Ellis (2008) mentions, originally came from general psychology. The term 'learning style' for the first time was used by Thelen (1954), although the term 'cognitive style' was proposed by 
Allport (1937) which basically means how your personality affects your way of living and adapting with the environment around. Keefe (1979) proposes that finding out about a person's learning style can help us to prepare the proper instruction for that person on a much more scientific and reliable basis.

A learning-style model "classifies students according to where they fit on a number of scales pertaining to the ways they receive and process information" (Felder, 1988, p. 674). To explain the concept of learning style, a lot of models have been proposed during the last decades. These models mostly are based on psychological theories and try to give an independent framework for studying this concept. Some of these models were primarily designed for specific disciplines like engineering or mathematics, while most of them were designed to study the learners' learning process in general. Some of these models which were used for learning process, and language learning process in specific, are 'The Myers-Briggs Type Indicator (MBTI)', 'Kolb's learning style model', 'Felder-Silverman learning style model', 'Dunn and Dunn learning style model', 'Fleming's The VARK model', and 'Reid's perceptual learning style model'. Reid (1987) for instance, distinguished four perceptual learning styles. They were visual, auditory, kinesthetic, and tactile learning. Felder (1988) also divides the ways people receive information into three categories or three modalities. In this study, Felder's division of learning styles is used as the basis. According to him, three modalities are: 'visual', using pictures and symbols, sights, models and diagrams, videos and films; 'auditory', using words, voices and sounds; and 'kinesthetic', using five basic senses, mostly touching, tasting and smelling. According to him, "an extensive body of research has established that most people learn most effectively with one of the three modalities and tend to miss or ignore information presented in either of the other two" (p. 676). Felder (1988) then describes each one of these modalities. Visual learners "remember best what they see... If something is simply said to them they will probably forget it". Auditory learners "remember much of what they hear and more of what they hear and then say. They get a lot out of discussion, prefer verbal explanation to visual demonstration, and learn effectively by explaining things to others" (p. 676). As for kinesthetic learners, we can say that they prefer to experience what they want to learn through senses other than visual and auditory senses. They like to be engaged physically with the topic, like touching, smelling, tasting, working with their hands and moving their bodies. This way they can learn and remember the lesson better.

The other ID factor used in this study is motivation. The importance of motivation in second language learning and acquisition is clear for most of the language learning stakeholders around the world nowadays. Lack of motivation can directly affect learning and decrease the learner's language achievement. This compels us to search for contemporary ways to make learners more motivated and hopefully to improve the quality of their learning process. To this end, investigating the parameters which affect learners' motivation level is required. Lots of factors can have effects on motivation. Researchers have been studying and theorizing about motivation and factors that affect it for so long (Au, 1988; Crookes \& Schmidt, 1991; Dornyei, 2005; Gardner, 1980, 1985, 2001; Williams \& Burden, 1997).

Williams and Burden (1997) try to see motivation through a constructivist perspective. They explain that:

A constructivist view of motivation centers around the premise that each individual is motivated differently. ...therefore what motivates one person to learn a foreign language and keeps that person going until he or she has achieved a level of proficiency with which he or she is satisfied will differ from individual to individual. (p. 120)

Dornyei and Skehan (2003) believe that motivation studies should pursue the basic question "why humans think and behave as they do" (p. 614). Important point to remember is that motivation is not constant but a changeable construct. Dornyei (2001) emphasizes on the dynamic and temporal nature of motivation. It is different from time to time, or as Dornyei and Skehan (2003) assert, “... is associated with a dynamically changing and evolving mental process” (p. 617). Aptitude and intelligence are said to be fixed cognitive attributes of the learner, motivation and anxiety, on the other hand, can often be changed and shaped through teacher intervention. In fact, it is not unusual for students to become more motivated with better attitude toward learning language as they progress.

\section{B. Learners' Interests and Homework}

What the learner's learning needs are is not necessarily the same as what they think their needs are. While the learning needs and target needs for a given intermediate classroom may be the same, each learner's view of his/her needs may vary from the others. Richterich (1984) commented that “... a need does not exist independent of a person. It is people who build their images of their needs on the basis of data relating to themselves and their environment" (p. 29).

It is really important for the material designers and teachers to understand the learners' wants and what they feel about the learning process. To this end, designing materials could be based on the learners' interests and passions.

Homework assignment, undeniably, is an important part of learning process. North and Pillary (2002) state that homework makes up a significant part of the workload of many language teachers, yet seems to be surrounded by silence and not much attention was given to it in literature. Cooper (1989) defines homework as "tasks assigned to students by school teachers that are meant to be carried out during non-school hours" (p. 7). Wong and Nunan (2011), as it was mentioned before, reached data which indicates that more effective learners have a much greater propensity for self- direction, independent learning and autonomy than less effective students. Now we know that spending some quality time for practicing language out of class has a strong long-term positive effect on learner's achievement. Therefore, we can indeed claim that homework, which is a kind of out-of-class activity, could reinforce and enrich the learners' knowledge. Of course the real challenge is finding a way to design more interesting and appropriate homework assignments so it could encourage the learners to spend even more time on it or at least motivate them to do the usual amount of assignments. 
Having this on mind, this study tries to acknowledge the personal differences of the learners and find a way to differentiate between them and then by making them actively involved in their learning process, improve their motivation. To reach this goal, it makes sense that learners' interests and their preferred learning style would be influential factors. Dunn, Debello, Brennan, Krimsky, and Murrain (1981) pointed out that "we can no longer afford to assume that all students will learn through whichever strategy the teacher prefers to use" (p. 1).

\section{Methodology}

The design of the present study is true experimental. Like all true experimental studies, this study comprises the necessary stages like pretest, pilot study, and posttest, and has all its necessary characteristics including randomization, experimental and control group, treatment, and placebo.

As the first step, based on the scores obtained in QPT (Quick Placement Test), 75 Iranian intermediate EFL learners were chosen. Then, 15 students were randomly assigned to the pilot study and the remained 60 participants were again randomly assigned to an experimental group and a control group; each group with 30 participants. A pretest (motivation test) was administered to the participants of both groups. For the next step, a structured interview with three questions to identify participants' favorite topic or their interests, and a learning style survey were executed on the participants in the experimental group. Next, the individualized versions of the homework were designed. These alternative homework assignments, or 'individualized homework assignments', were developed according to the learners' interests and their learning styles and were equivalents for the usual homework assignments which were assigned to the control group. The participants of the experimental group received a 20 -session treatment, which was assigning individualized homework to them. At the end of the treatment, a posttest, which was the same motivation test but with shuffled items, was administered to both groups to measure and analyze the impacts of the treatments on the experimental group.

Internal consistency reliability or Cronbach's Alpha coefficient (named after L. J. Cronbach) was recalculated for this study. According to this calculation, the Cronbach's Alpha for pretest and posttest came to .74 and .72 respectively, which are considered acceptable according to reliability standards recommended by Barker, Pistrang, and Elliott (1994), and Dornyei (2007). As for learning style survey, the Cronbach Alpha came to .71.

\section{A. Participants}

The participants were 41 male and 19 female EFL learners between the age of 16 and 21 at two private institutes, in Rasht, Iran. 122 learners were submitted and then were homogenized through QPT. The participants with the QPT scores between 30 and 44 were considered intermediate and selected as the main sample. Then, by using a randomizer computer application, they were randomly assigned to experimental and control groups. Both groups' participants were interviewed individually and were asked about their interests and passions (whether they like art, sports, or other topics), and the learning style survey was also administered to them. After the pretest (Dornyei and Taguci's (2009) Motivation test), the participants in experimental classes received the individualized equivalents of usual homework assignments of American English File 3 book during a 20-session course. These individualized homework assignments were prepared based on participants' interests and their preferred learning style before starting the course.

\section{B. Procedures for Data Collection}

To test the homogeneity of the participants, QPT (Version 1) was administered. When it was certain that the groups were homogeneous, both experimental and control groups followed the same syllabus, which was the first three lessons in the coursebook American English File 3 (Second Edition). As for homework, all of the 30 participants in control group received the same and usual homework which was mostly based on the workbook of the coursebook, but each one of the participants in experimental group received their own individualized version of homework assignments based on their unique interests and learning style, which was developed and prepared before the course started. The writing, reading, listening, grammar and vocabulary exercises and activities in homework assignments were different for each learner. For example, for students with 'visual' learning style, and based on their genuine interest which could be art or sport or others (e.g. videogames), extracts of conversation from movies, or interviews with famous singers or actors, or even extracts from reporters' conversation between two halves of a football match, were chosen according to the related lesson. For 'auditory' students, audio extracts from movie conversations and TV live shows (e.g. 'Inside Actors Studio' $T V$ show) and also radio reports of sport events were used. To 'kinesthetic' learners, the activities like pantomime, and projects like making albums of different artists with related pictures and information were assigned. It is needless to say that all exercises or activities were designed as equivalents of exercises and activities which were given to the control group. The course continued for 20 sessions, three hours a week.

At the end of the course, a posttest which was piloted before with a reliability index higher than .7, was administered to the participants to measure their progress during the course. The posttest and the pretest was actually the same test with rearranged items to control the potential testing effect. Next, with the help of an independent samples t-test, the means of the two groups in the posttest were compared with the alpha level set at 0.05 . The lowest and highest scores for the pretest and the posttest were zero and 456 respectively. Finally, with running a paired samples t-tests, the means of both groups were compared. 


\section{MATERIALS}

The required data for this research was mainly collected quantitatively. Except the three-question structured interview for recognizing the interests of the learners, the rest of the data gathered by standard questionnaires. The following instruments were used in this study.

\section{A. Pretest}

The First step was using QPT and creating two randomly assigned groups with 30 intermediate level learners in each of them. Next, Dornyei and Taguchi's (2009) motivation test was used as the pretest in this study and was administered before the course started. The purpose of this pretest was to recognize the participants' motivation level and the initial differences among the groups with respect to their motivation. The motivation test consisted four parts and included 76 items overall with scales from 'strongly disagree' to 'strongly agree' for statement-type items or part 1 and part 3, and 'not at all' to 'very much' for question-type items or part 2, with scores 1 to 6 respectively. Dornyei and Taguchi's (2009) motivation test in English version is presented in Appendix A.

\section{B. Learning Style Survey}

To identify the learning style preferences of the learners, Cohen, Oxford, and Chi's (2003) 'The Learning Style Survey' created by the University of Minnesota was administered. The test consisted 11 parts, but for the purpose of this study, the first part which included 30 items and could identify the learners' physical sense preferences was chosen. The scales were from 'never' with the score zero, to 'always' with the score 4. After translation of the 30-question questionnaire to Persian, three English translation specialists confirmed its face and content validity. This way, the Persian version of the questionnaire was prepared and given to the learners. The original version of the learning style survey is presented in Appendix B.

\section{Structured Interview}

In this study a structured interview with three questions was administered. These questions aimed to recognize the learners' field of interest (art, sports, or others), (see Appendix C).

\section{Posttest}

After the 20-session treatment and at the end of the course, which was about three months, Dornyei and Taguchi's (2009) motivation test was again administered as the posttest but the whole 76 items were rearranged. This rearrangement was necessary in order to control the possible testing effect.

\section{DATA ANALYSIS AND RESUltS}

The estimated values for Cronbach's Alpha for the pretest of motivation came to $(\alpha=.72)$, for posttest of motivation came to $(\alpha=.74)$, and for learning style test came to $(\alpha=.71)$ which were considered acceptable according to the reliability standards recommended by Barker, Pistrang, and Elliott (1994). To select subjects who were nearly at equal level of language proficiency, the Standardized Oxford Quick Placement Test (Version 1) was given to $(\mathrm{N}=122)$ EFL learners. Before introducing the treatment, a pretest including 76 items was administered to all the participants in the control and experimental groups. The purpose for administering the pretest at the beginning of the study was to examine the learners' motivation level and also to set a baseline measurement to compare it with the results of the posttest in the end of the course. For the pretest of motivation, the means for the experimental group and the control group were (Xexperimental group $=301.80)$, and $(X$-control group $=309.13)$, respectively. The mean score of the control group was (7.33) points higher than that of the experimental group.

After establishing the normality assumption and administering the pretest, and before starting the course, an independent samples t-test was run to compare two groups and confirm that there are no statistically significant difference between them. The results are available in Table I.

TABLE I

INDEPENDENT SAMPLES T-TEST FOR PRETEST

\begin{tabular}{|c|c|c|c|c|c|c|c|c|c|}
\hline & \multicolumn{2}{|c|}{$\begin{array}{l}\text { Levene's Test for } \\
\text { Equality of } \\
\text { Variances }\end{array}$} & \multicolumn{5}{|c|}{ t-test for Equality of Means } & & \\
\hline & \multirow[t]{2}{*}{$\mathbf{F}$} & \multirow[t]{2}{*}{ Sig. } & \multirow[t]{2}{*}{$\mathbf{T}$} & \multirow[t]{2}{*}{ Df } & \multirow[t]{2}{*}{$\begin{array}{l}\text { Sig. } \\
\text { (2-tailed) }\end{array}$} & \multirow[t]{2}{*}{$\begin{array}{l}\text { Mean } \\
\text { Difference }\end{array}$} & \multirow[t]{2}{*}{$\begin{array}{l}\text { Std. Error } \\
\text { Difference }\end{array}$} & \multicolumn{2}{|c|}{$\begin{array}{l}\text { 95\% Confidence Interval } \\
\text { of the Difference }\end{array}$} \\
\hline & & & & & & & & Lower & Upper \\
\hline $\begin{array}{l}\text { Equal } \\
\text { variances } \\
\text { assumed } \\
\end{array}$ & 1.028 & .315 & .704 & 58 & .484 & 7.333 & 10.422 & -13.528 & 28.195 \\
\hline $\begin{array}{l}\text { Equal } \\
\text { variances not } \\
\text { assumed }\end{array}$ & & & .704 & 56.32 & .485 & 7.333 & 10.422 & -13.542 & 28.208 \\
\hline
\end{tabular}


The independent samples t-test displayed the results of the Levene's test for the equality of variances. This attempted whether the dispersion of scores for the two groups was the same for the pretest scores. The outcome established the correct t-value for the interpretation of scores for the test. Since the Sig. value for Levene's test was higher than (.05), the first row in the table, which referred to Equal variances assumed, was utilized for explaining the results of the pretest. In Table 1, the significance level for the Levene's test was (.315) which was higher than (.05). This meant that the assumption of equal variances had not been violated for the pretest scores. Moreover, since the value in the Sig. (2tailed) column was higher than the cut-off of (.05), there were no significant differences in the mean scores of the motivation test for the control and experimental groups. In other words, the control and experimental groups were almost at the same level of motivation at the beginning of the study. The main objective of the present study was to determine the impact of assigning individualized homework on Iranian intermediate EFL learners' motivation level. The hypothesis was that the aforementioned homework materials does not have any statistically significant impact on EFL learners' motivation. After 20 sessions of treatment, the posttest of motivation was administered to both control and experimental groups. II.

An independent samples t-test was run to compare the two groups after the treatment. The results are shown in Table

The results revealed that the significance value of the Levene's test was $(\mathrm{P}=.683)$. Since this rating was higher than .05 , it will be assumed that the control and experimental groups had equal variances; therefore the first row of the table was reported. Since the significance value Sig. (2-tailed) was lower than .05 , it could be concluded that there was a significant difference between the two groups concerning their level of motivation in the posttest. These findings supported the results of descriptive analysis in which there was a difference between the two groups regarding the mean scores, i.e. the experimental group outperformed the control group. Thus the null hypothesis was rejected suggesting that there were in fact statistically significant differences between the two groups at the end of the study. In other words, assigning homework materials based on the learners' learning style and interests instead of using the same notindividualized materials for all the learners has statistically significant effect on Iranian intermediate EFL learners' motivation level.

In order to examine the participants' progress within groups, two paired samples t-tests were conducted, which highlighted the differences in the posttest of motivation. The results of paired samples statistics are reported in Table III.

TABLE II.

INDEPENDENT SAMPLES T-TEST FOR POSTTEST

\begin{tabular}{|c|c|c|c|c|c|c|c|c|c|}
\hline & \multicolumn{2}{|c|}{$\begin{array}{l}\text { Levene's Test for } \\
\text { Equality of Variances }\end{array}$} & \multicolumn{5}{|c|}{ t-test for Equality of Means } & \multirow{2}{*}{\multicolumn{2}{|c|}{$\begin{array}{l}95 \% \text { Confidence } \\
\text { Interval of the } \\
\text { Difference }\end{array}$}} \\
\hline & \multirow[t]{2}{*}{$\mathbf{F}$} & \multirow[t]{2}{*}{ Sig. } & \multirow[t]{2}{*}{$\mathbf{t}$} & \multirow[t]{2}{*}{ df } & \multirow{2}{*}{$\begin{array}{l}\text { Sig. } \\
\text { (2-tailed) }\end{array}$} & \multirow{2}{*}{$\begin{array}{l}\text { Mean } \\
\text { Difference }\end{array}$} & \multirow{2}{*}{$\begin{array}{l}\text { Std. Error } \\
\text { Difference }\end{array}$} & & \\
\hline & & & & & & & & Lower & Upper \\
\hline $\begin{array}{l}\text { Equal variances } \\
\text { assumed }\end{array}$ & .169 & .683 & -2.103 & 58 & .031 & -20.333 & 9.686 & -39.534 & -.981 \\
\hline $\begin{array}{l}\text { Equal variances } \\
\text { not assumed }\end{array}$ & & & -2.103 & 56 & .031 & -20.333 & 9.686 & -39.540 & -.973 \\
\hline
\end{tabular}

TABLE III.

PAIRED SAMPLES T-TEST FOR CONTROL AND EXPERIMENTAL GROUPS

\begin{tabular}{llllll}
\hline & & Mean & N & Std. Deviation & Std. Error Mean \\
\hline Pair 1 & CONTROLpretest- & 309.13 & 30 & 43.706 & 7.980 \\
\cline { 2 - 6 } & CONTROLposttest & 304.87 & 30 & 39.663 & 7.241 \\
\hline \multirow{2}{*}{ Pair 2 } & EXPERIMENTALpretst- & 301.80 & 30 & 36.719 & 6.704 \\
\cline { 2 - 6 } & EXPERIMENTALposttest & 326.07 & 30 & 34.785 & 6.351 \\
\hline
\end{tabular}

The mean score of the control group for the motivation test was not improved, while the mean score of the experimental group increased from $(M=301.80)$ in pretest to $(M=326.07)$ in posttest. In order to find out if these differences between pretest and posttest scores of motivation were statistically significant, paired samples t-test was run to the results of both groups. The results are presented in Table IV.

TABLE IV.

PAIRED SAMPLES T-TEST FOR PRETEST AND POSTTEST

\begin{tabular}{|c|c|c|c|c|c|c|c|c|c|}
\hline & & \multicolumn{5}{|c|}{ Paired Differences } & \multirow{3}{*}{$\mathbf{T}$} & \multirow{3}{*}{ df } & \multirow{3}{*}{$\begin{array}{l}\text { Sig. } \\
\text { (2-tailed) }\end{array}$} \\
\hline & & \multirow[t]{2}{*}{ Mean } & \multirow[t]{2}{*}{$\begin{array}{l}\text { Std. } \\
\text { Deviation }\end{array}$} & \multirow[t]{2}{*}{$\begin{array}{l}\text { Std. } \\
\text { Error } \\
\text { Mean }\end{array}$} & \multicolumn{2}{|c|}{$\begin{array}{l}95 \% \text { Confidence } \\
\text { Interval of the } \\
\text { Difference }\end{array}$} & & & \\
\hline & & & & & Lower & Upper & & & \\
\hline Pair 1 & $\begin{array}{l}\text { CONTROLpre- } \\
\text { CONTROLpost }\end{array}$ & 4.267 & 14.802 & 2.702 & -1.260 & 9.794 & 1.579 & 29 & .125 \\
\hline Pair 2 & $\begin{array}{l}\text { EXPERIMENTALpre- } \\
\text { EXPERIMENTALpost }\end{array}$ & -24.267 & 19.881 & 3.630 & -31.690 & -16.843 & -6.686 & 29 & .000 \\
\hline
\end{tabular}

As depicted in Tables III and IV, no improvement is seen for control group, but experimental group had improvement in the posttest of motivation. Based on the results of paired samples t-test, the improvement in the 
experimental group was statistically significant $\left(\mathrm{P}_{\text {experimental group }}<0.05\right)$, but this was not the case for control group $\left(\mathrm{P}_{\text {control group }}>0.05\right)$. In other words, the experimental group made a noticeably higher progression as compared to the control group in posttest of motivation

\section{DISCUSSION}

The findings of the present study are in line with the framework of cognitive psychology which emphasizes on making learners more actively involved in their learning process. Constructivists like Piaget (1966, 1972), and Atkinson and Shiffrin (1968) basically believe that making the learners involved in their own learning process can have great positive effects on the quality of their learning. In this study, it was shown that using individualized homework assignments designed based of each learner's characteristics have positive effects on the learners' motivation, which confirmed constructivists' point of view.

There have been always controversies about learning style studies. Some researchers have a cautious attitude toward such studies, and some even reject them completely. Most of these criticisms come from the very researchers who have done a lot of studies in this field and proposed some of the most important models and theories about learning styles. In order to have a fair look to this field, it is necessary to review some of these criticisms here.

Kolb (1981) brilliantly warns us against putting learners into stereotypical categories and treat them accordingly and at the same time being insensitive to the context in which they are living or studying. Schmeck (1981) also believes that the context is very influential and many of learners can change their strategies according to the contextual demands. This emphasize on the role of context was again reminded by Dornyei and Skehan (2003) who describe learning style as "a predisposition may be deep seated", but at the same time "imply some capacity for flexibility... to meet the demands of particular circumstances" (p. 602). Felder (1996) brings out another interesting point and explains that it is not desirable for learners to just master one of the learning styles and forget about the others. He emphasizes that in any professional capacity, you need to have ability in all learning style modes. For example, to achieve success in learning second language, it is better if the learner develop both 'verbal' and 'visual' skills. So the teachers should help learners to improve all their learning skills, instead of focusing on just one of them.

Another important criticism is that because of the origin of learning style studies which was in general psychology, global psychological instruments primarily were used to measure them, and these instruments "may not be well suited for identifying the specific nature of learning styles that influence language learning” (Ellis, 2008, p. 659). Ellis (2008) also mentions that these learning styles might be situation-specific.

To summarize, if we are going to help the learning process by making the learning experience enjoyable for the learners, acknowledging the learners' individuality, especially their learning style, could be the answer. Ehrman et al. (2003) explains that it is very much possible to make language learners more relaxed and comfortable if we could just let them work and learn in their own preferred learning style, instead of forcing them to learn in a specific, usually not in accord with their learning style, way just because it is being used in the classroom.

\section{CONCLUSION}

This study attempted to examine the effectiveness of using individualized homework in improving motivation level of Iranian intermediate EFL learners. The findings of the study showed that using individualized homework has positive effects on the learners' motivation. Based on the results of this study, the experimental group who received the use of individualized homework made more improvement in the posttest of motivation. In other words, the use of homework assignments based on learners' interests and preferred learning style makes Iranian intermediate EFL learners more motivated for learning. Hence, the null hypothesis proposed at the beginning of the study was rejected.

The findings obtained in this study lead to some pedagogical implications which are beneficial for different stakeholders in the field of language teaching and learning. Curriculum and materials developers, course and syllabus designers, learners, teachers, and teacher trainers are among those who can use the findings of this study to improve the condition and status of language teaching in the context of Iran. Teachers know the important role of homework in the learning process, but there are always reasons to be concerned about learners' enthusiasm for doing their homework. Furthermore, as Cooper (1989) emphasizes, due to absence of professional supervisor, there are always dangers like satiation (physical and emotional fatigue), parental interference, and cheating which concern teachers. Considering the findings of the current study, language teachers can design proper materials for homework assignment based on each learner's unique characteristic and interests. Utilizing individualized homework in EFL classes can provide tremendous opportunities for learners to improve their language achievement compared to traditional way of giving similar homework assignments to all the learners regardless of what they really like and what their learning styles are. In classes in which homework assignments are individualized beforehand and prepared based on each individual's wants and preferred learning style, learners can enjoy from learning a new language.

All in all, this study recommends applying individualized homework in EFL contexts where learners are not particularly enthusiastic about doing homework or learning outside of the classroom, or the contexts in which the majority of the learners have instrumental motivation or their motivation level is low. 
Every useful study opens new directions for further studies. Further research can be expanded to a larger sample to increase the credibility of the results. In this study, only intermediate-level EFL learners were considered. Other proficiency levels can be considered in a similar research. Also, learners in this study were between 16 and 21 years old. Further studies can examine various age groups. In this study, the effects of using homework assignments based on learners' preferred learning style on Iranian EFL learners' motivation were analyzed. In further studies, researchers can check the effects of other individual differences like 'learning strategies', 'personality', and 'intelligence' on the learners' motivation.

\section{ApPendix A. Dornyei And Taguci’s (2009) Motivation Test (English Version)}

\section{English Learner Questionnaire}

This survey is conducted by the School of English Studies of the University of Nottingham, UK, to better understand the thoughts and beliefs of learners of English. This questionnaire consists of four sections. Please read each instruction and write your answers. This is not a test so there are no "right" or "wrong" answers and you do not even have to write your name on it. The results of this survey will be used only for research purpose so please give your answers sincerely. Thank you very much for your help!

\section{Part I}

In this part, we would like you to tell us how much you agree or disagree with the following statements by simply circling a number from 1 to 6 . Please do not leave out any of items.

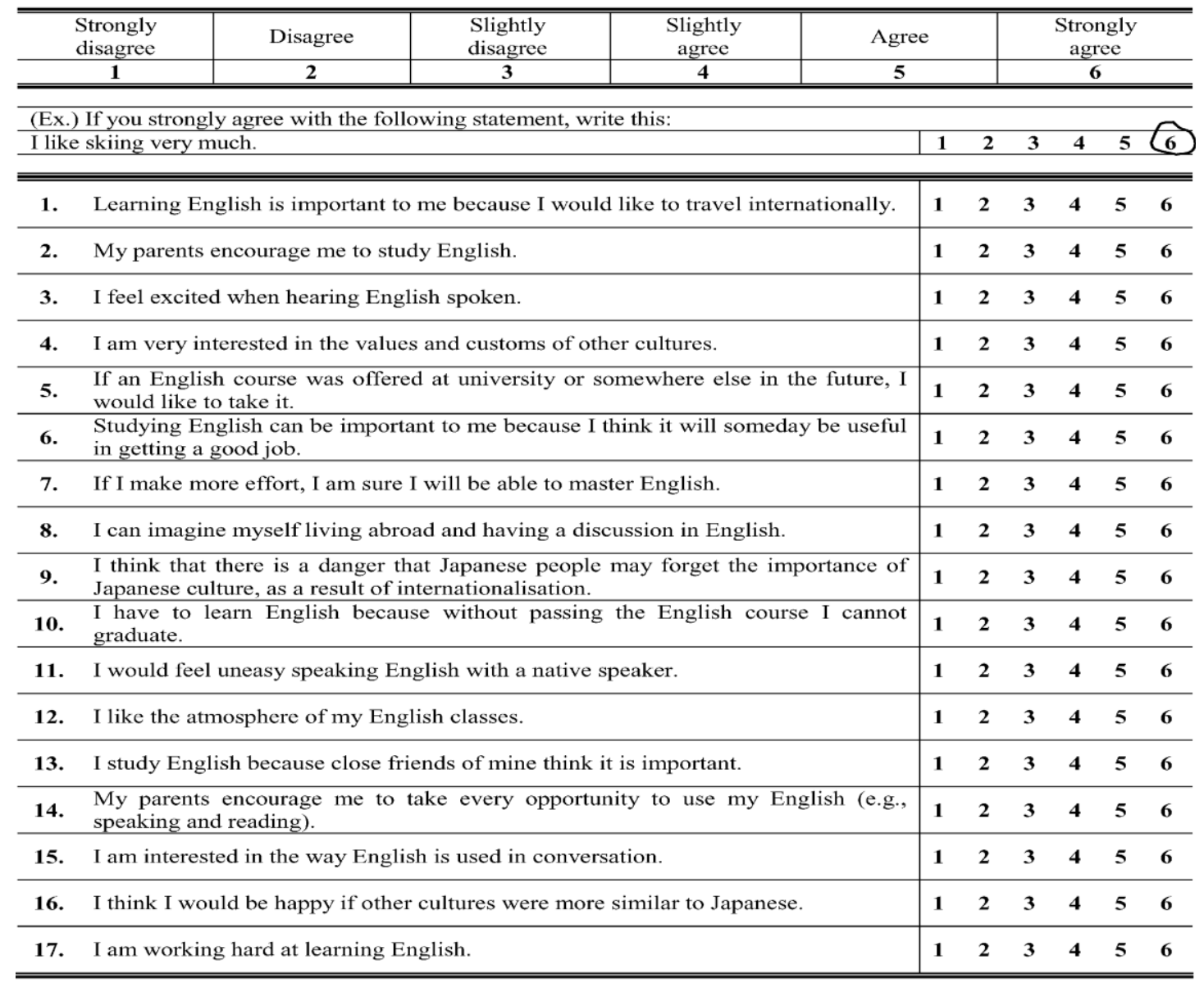




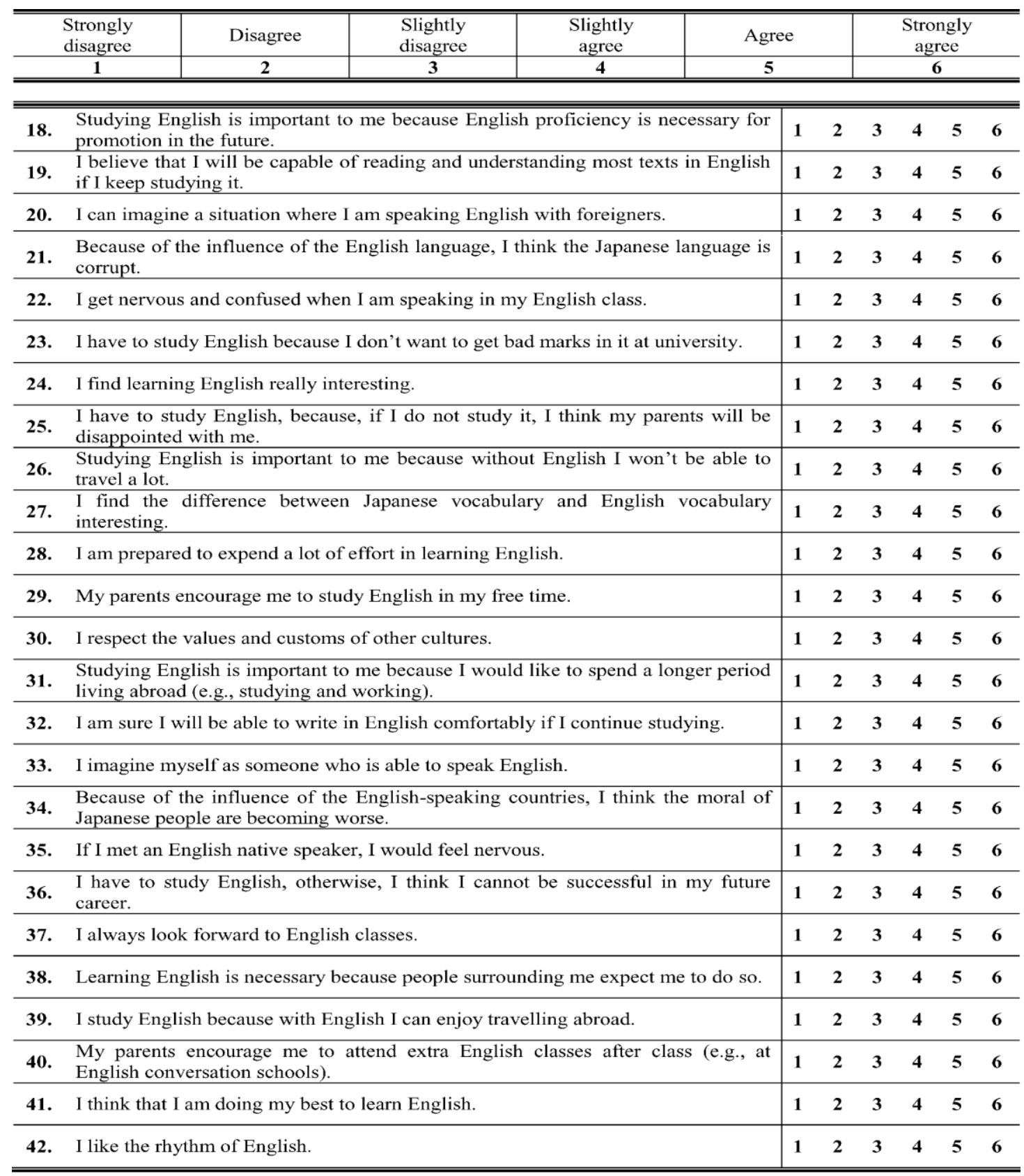




\section{Part II}

These are new questions but please answer them the same way as you did before.

\begin{tabular}{|c|c|c|c|c|c|c|c|c|c|c|}
\hline Not at all & Not so much & So-so & A little & \multirow{2}{*}{\multicolumn{2}{|c|}{$\frac{\text { Quite a lot }}{5}$}} & & \multicolumn{4}{|c|}{ Very much } \\
\hline 1 & $\mathbf{2}$ & 3 & 4 & & & & \multicolumn{4}{|c|}{6} \\
\hline \multicolumn{11}{|c|}{ (Ex.) If you like "curry" very much, write this: } \\
\hline \multicolumn{5}{|c|}{ Do you like curry? } & 1 & 2 & 3 & 4 & 5 & 6 \\
\hline \multicolumn{5}{|c|}{ 43. Do you like the music of English-speaking countries (e.g., pop music)? } & 1 & 2 & 3 & 4 & 5 & 6 \\
\hline \multicolumn{5}{|c|}{ 44. Do you like to travel to English-speaking countries? } & 1 & 2 & 3 & 4 & 5 & 6 \\
\hline \multicolumn{5}{|c|}{$\begin{array}{l}\text { 45. How important do you think learning English is in order to learn more about the } \\
\text { culture and art of its speakers? }\end{array}$} & 1 & 2 & 3 & 4 & 5 & 6 \\
\hline \multicolumn{5}{|c|}{ 46. Do you like English films? } & 1 & 2 & 3 & 4 & 5 & 6 \\
\hline \multicolumn{5}{|c|}{ 47. Do you like the people who live in English-speaking countries? } & 1 & 2 & 3 & 4 & 5 & 6 \\
\hline \multicolumn{5}{|c|}{ 48. How much would you like to become similar to the people who speak English? } & 1 & 2 & 3 & 4 & 5 & 6 \\
\hline \multicolumn{5}{|c|}{ 49. Do you like English magazines, newspapers, or books? } & 1 & 2 & 3 & 4 & 5 & 6 \\
\hline \multicolumn{5}{|c|}{ 50. Do you like meeting people from English-speaking countries? } & 1 & 2 & 3 & 4 & 5 & 6 \\
\hline \multicolumn{5}{|c|}{ 51. How much do you like English? } & 1 & 2 & 3 & 4 & 5 & 6 \\
\hline \multicolumn{5}{|c|}{ 52. Do you like TV programmes made in English-speaking countries? } & 1 & 2 & 3 & 4 & 5 & 6 \\
\hline \multicolumn{5}{|c|}{ Would you like to know more about people from Englis } & 1 & 2 & 3 & 4 & 5 & 6 \\
\hline
\end{tabular}

\section{Part III}

The following items are similar to the ones in Part 1.

\begin{tabular}{|c|c|c|c|c|c|c|c|c|c|c|c|}
\hline & $\begin{array}{l}\text { Strongly } \\
\text { disagree }\end{array}$ & Disagree & $\begin{array}{l}\text { Slightly } \\
\text { disagree }\end{array}$ & $\begin{array}{l}\text { Slightly } \\
\text { agree }\end{array}$ & \multicolumn{3}{|c|}{ Agree } & \multicolumn{4}{|c|}{$\begin{array}{l}\text { Strongly } \\
\text { agree }\end{array}$} \\
\hline & 1 & 2 & 3 & 4 & \multicolumn{2}{|l|}{5} & & \multicolumn{3}{|c|}{6} & \\
\hline 54. & \multicolumn{5}{|c|}{ It would be a better world if everybody lived like the Japanese. } & 1 & 2 & 3 & 4 & 5 & 6 \\
\hline 55. & \multicolumn{5}{|c|}{$\begin{array}{l}\text { Studying English can be important for me because I think I'll need it for further } \\
\text { studies on my major. }\end{array}$} & 1 & 2 & 3 & 4 & 5 & 6 \\
\hline 56. & \multicolumn{5}{|c|}{$\begin{array}{l}\text { I think the cultural and artistic values of English are going at the expense of } \\
\text { Japanese values. }\end{array}$} & 1 & 2 & 3 & 4 & 5 & 6 \\
\hline 57. & \multicolumn{5}{|c|}{ I am sure I have a good ability to learn English. } & 1 & 2 & 3 & 4 & 5 & 6 \\
\hline 58. & \multicolumn{5}{|c|}{ Whenever I think of my future career, I imagine myself using English. } & 1 & 2 & 3 & 4 & 5 & 6 \\
\hline 59. & \multicolumn{5}{|c|}{ I would get tense if a foreigner asked me for directions in English. } & 1 & 2 & 3 & 4 & 5 & 6 \\
\hline 60. & \multicolumn{5}{|c|}{$\begin{array}{l}\text { Studying English is necessary for me because I don't want to get a poor score or a } \\
\text { fail mark in English proficiency tests. }\end{array}$} & 1 & 2 & 3 & 4 & 5 & 6 \\
\hline
\end{tabular}




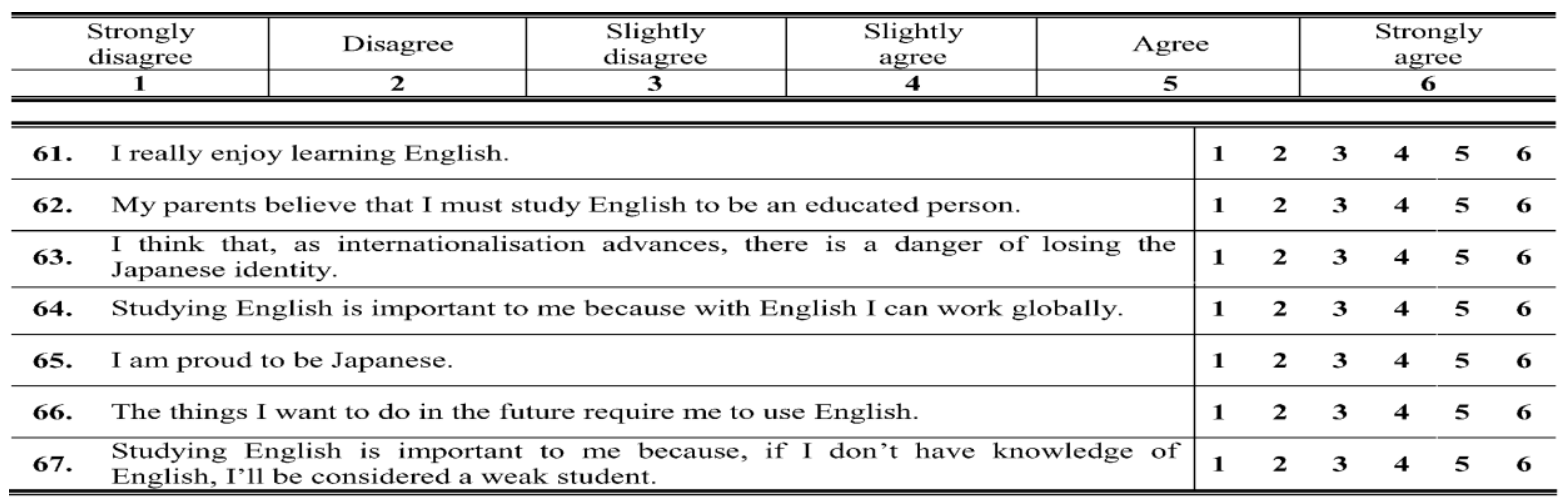

\section{Part IV}

Please provide the following information by ticking ( $)$ in the box or writing your response in the space.

Gender:

a Male $\square$ Female

Nationality:

Age:

Year of study:

Major:

English teacher

$$
\text { Japanese } \square \text { Non-Japanese }
$$

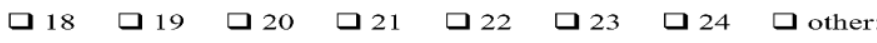

$\square 1^{\text {st }} \square 2^{\text {nd }} \square 3^{\text {rd }} \square 4^{\text {th }} \square 5^{\text {th }} \square$ other:

Have you ever had or do you have a native English-speaking teacher?

口 Yes a No

Overseas experiences: Have you spent a longer period (at least a total of three months) in English-speaking countries (e.g., travelling, studying)?

口Yes $\square$ No

English ability: $\quad$ Please rate your current overall proficiency in English by ticking one.

U Upper Intermediate level and over-Able to converse about general matters of daily life and topics of one's specialty and grasp the gist of lectures and broadcasts. Able to read high-level materials such as newspapers and write about personal ideas.

口 Intermediate level - Able to converse about general matters of daily life. Able to read general materials related to daily life and write simple passages.

Lower Intermediate level - Able to converse about familiar daily topics. Able to read materials about familiar everyday topics and write simple letters.

Post-Beginner level - Able to hold a simple conversation such as greeting and introducing someone. Able to read simple materials and write a simple passage in elementary English.

Beginner level - Able to give simple greetings using set words and phrases. Able to read simple sentences, grasp the gist of short passages, and to write a simple sentence in basic English.

\section{Thank you for your cooperation!}

\section{APPENDiX B. LEARNing STYLE SURVEy (ENGLiSh Version)}

\section{Learning Style Survey: Assessing Your Own Learning Styles}

Andrew D. Cohen, Rebecca L. Oxford, and Julie C. Chi

The Learning Style Survey1 is designed to assess your general approach to learning. It does not predict your behavior in every instance, but it is a clear indication of your overall style preferences. For each item, circle the response that represents your approach. Complete all items. There are 11 major activities representing 12 different aspects of your learning style. When you read the statements, try to think about what you usually do when learning. It typically takes about 30 minutes to complete the survey. Do not spend too much time on any item-indicate your immediate feeling and move on to the next item.

For each item, circle your response:

$$
\begin{aligned}
& \mathbf{0}=\text { Never } \\
& 1=\text { Rarely } \\
& 2=\text { Sometimes } \\
& 3=\text { Often } \\
& 4=\text { Always }
\end{aligned}
$$

Part 1: HOW I USE MY PHYSICAL SENSES

1. I remember something better if I write it down. 01234 
2. I take detailed notes during lectures. 01234

3. When I listen, I visualize pictures, numbers, or words in my head. 01234

4. I prefer to learn with TV or video rather than other media. 01234

5. I use color-coding to help me as I learn or work. 01234

6. I need written directions for tasks. 01234

7. I have to look at people to understand what they say. 01234

8. I understand lectures better when professors write on the board. 01234

9. Charts, diagrams, and maps help me understand what someone says. 01234

10. I remember peoples' faces but not their names. 01234

A - Total:

11. I remember things better if I discuss them with someone. 01234

12. I prefer to learn by listening to a lecture rather than reading. 01234

13. I need oral directions for a task. 01234

14. Background sound helps me think. 01234

15. I like to listen to music when I study or work. 01234

16. I can understand what people say even when I cannot see them. 01234

17. I remember peoples' names but not their faces. 01234

18. I easily remember jokes that I hear. 01234

19. I can identify people by their voices (e.g., on the phone). 01234

20. When I turn on the TV, I listen to the sound more than I watch the screen. 01234

$$
\text { B - Total: ........ }
$$

21. I prefer to start doing things rather than checking the directions first. 01234

22. I need frequent breaks when I work or study. 01234

23. I need to eat something when I read or study. 01234

24. If I have a choice between sitting and standing, I'd rather stand. 01234

25. I get nervous when I sit still too long. 01234

26. I think better when I move around (e.g., pacing or tapping my feet). 01234

27. I play with or bite on my pens during lectures. 01234

28. Manipulating objects helps me to remember what someone says. 01234

29. I move my hands when I speak. 01234

30. I draw lots of pictures (doodles) in my notebook during lectures. 0112234

Part 1- Total:

C - Total: ......

The format of the Learning Style Survey and a number of the dimensions and items are drawn from Oxford; other key dimensions and some of the wording of items comes from Ehrman and Leaver:

Oxford, R. L. (1995). Style Analysis Survey. In J. Reid (Ed.), Learning styles in the ESL/EFL classroom (pp. 208215). Boston: Heinle \& Heinle/Thomson International.

Ehrman, M. E. \& Leaver, B. L. (2003). Cognitive styles in the service of language learning. System 31: 393-415.

Regents of the University of Minnesota. These materials were created for the Maximizing Study Abroad series, published by the Center for Advanced Research on Language Acquisition at the University of Minnesota. Permission is granted to make copies of this handout for classroom use. Permission to make copies of any other part of the book or to reprint any part of the book in another publication must be sought from the CARLA office (http://www.carla.umn.edu).

\section{APPENDix C. STRUCTURED INTERVIEW (For IDENTIFYING LEARNERS' FIELD OF INTEREST)}

\section{In the name of God}

This interview aims to find out about your personal interests and passions in life. It consists of three structured questions. Please answer each question sincerely with details and elicit about them. This is not a test, so we do not have any 'right' or 'wrong' answers. The results of this interview will be used only for research purposes and can help your language learning. This interview will be recorded for further analysis.

Thank you.

Question 1: Which one of the following exercises is your favorite and you are better at it? Explain why do you think that is?
A) Writing exercises
B) Reading Comprehension exercises 
C) Listening exercises

Question 2: Which one of the following is your favorite field?

$\begin{array}{lll}\text { A) Art } & \text { B) Sport } & \text { C) Others }\end{array}$

-If you chose 'Art', do you prefer 'Music' or 'Movies'? Explain.

-If you chose 'Sport', do you prefer 'Football' or other sports? Name it.

-If you chose 'Others', please explain.

Question 3: If you practice in your field of interest, for example play a musical instrument or play in a sport team, please talk about it.

Thank you for your time.

\section{REFERENCES}

[1] Allport, G. W. (1937). Personality: A Psychological Interpretation. Henry Holt and Company, New York.

[2] Anastasi, A. (1958). Heredity, environment, and the question" How?". Psychological Review, 65(4), 197-198.

[3] Atkinson, R. C., \& Shiffrin, R. M. (1968). Human memory: A proposed system and its control processes. Psychology of learning and motivation, 2, 89-195.

[4] Au, S. (1988). A critical appraisal of Gardner's social-psychological theory of second language (L2) learning. Language Learning, 38, 75-100.

[5] Barker, C., Pistrang, N., \& Elliot, R. (1994). Research methods in clinical and counseling psychology. John Wiley \& Sons. West Sussex, England.

[6] Birch, A., \& Hayward, S. (1994). Individual differences. Basingstoke: Macmillan.

[7] Carrol, J. B., \& Sapon, S. (1959). The modern language aptitude test. San Antonio, TX: Psychological Corporation.

[8] Cohen, A. D., Oxford, R. L., \& Chi, J. C. (2003). Learning style survey: Assessing your own learning styles. Regents of the University of Minnesota, 151-161.

[9] Cooper, H. M. (1989). Homework. White Plains, N.Y.: Longman.

[10] Crookes, G., \& Schmidt, R. (1991). Language learning motivation: reporting the research agenda. Language learning, 41, 469512.

[11] De Raad, B. (2000). The Big Five Personality Factors: The psycholexical approach to personality. Ashland, OH: Hogrefe \& Huber Publishers.

[12] Dörnyei, Z. (2001). Teaching and researching motivation. Harlow: Longman.

[13] Dörnyei, Z. (2005). The psychology of the language learner: Individual differences in second language acquisition. Mahwah, N.J.: Lawrence Elbraum.

[14] Dörnyei, Z. (2007). Research methods in applied linguistics. Oxford: Oxford University Press.

[15] Dörnyei, Z., \& Taguchi, T. (2009). Questionnaires in second language research: Construction, administration, and processing. London, UK: Routledge.

[16] Dörnyei, Z., \& Skehan, P. (Eds.). (2003). Individual differences in second language learning. The handbook of second language acquisition, 589-630.

[17] Dunn, R., Debello, T., Brennan, P., Krimsky, J., \& Murrain, P. (1981). Learning style researchers define differences differently. Educational Leadership, 38(5), 372-375.

[18] Ehrman, M. E. (1996). Understanding second language difficulties. Thousand Oakes, CA: Sage.

[19] Ehrman, M. E., Leaver, B. L., \& Oxford, R. L. (2003). A brief overview of individual differences in second language learning. System 31, 313-330.

[20] Ellis, R. (2008). The study of second language acquisition. Oxford: Oxford University Press.

[21] Eysenck, H. J. (1994). Personality and intelligence: Psychometric and experimental approaches. Personality and intelligence, 1 , 3-31.

[22] Felder, R. M. (1988). Learning and teaching styles in engineering education. Engr. Education, 78(7), 674-681.

[23] Felder, R. M. (1996). Matter of style. ASEE Prism, 6(4), 18-23.

[24] Gardner, R. C. (1980). On the validity of affective variables in second language acquisition: conceptual, contextual, and statistical considerations. Language Learning, 30, 255-270.

[25] Gardner, R. C. (1985). Social psychological and second language learning: The role of attitude and motivation. London: Edward Arnold.

[26] Gardner, R. C. (2001). Integrative motivation and second language acquisition. In Z. Dornyei \& R. Schmidt (Eds.): Motivation and second language learning. Honolulu: University of Hawaii's Press.

[27] Gardner, R. C., \& Lambert, W. E. (1959). Motivational variables in second language acquisition. Canadian Journal of Psychology, 13, 266-272.

[28] Gardner, R. C., \& MacIntyre, P. D. (1992). A student's contribution to second language learning: Part I, Cognitive factors. Language Teaching, 25, 211-220.

[29] Keefe, J. (1979a). Learning style: an overview. In J. Keefe (Ed.): Student learning styles: Diagnosing and describing programs. Reston Va.: National Secondary School Principals.

[30] Keefe, J. (Ed.). (1979b). Student learning styles: Diagnosing and describing programs. Reston Va.: National Secondary School Principals.

[31] Kolb, D. A. (1981). Learning styles and disciplinary differences. In A. Chickering, (Ed.). The modern American college. San Francisco, CA: Jossey Bass.

[32] Kumaravadivelu, B. (2006). Understanding language teaching: From method to postmethod. New Jersey: Lawrence Erlbaum Associates. 
[33] MacIntyre, P.D. (1999). Language anxiety: A review of the research for language teachers. In D. J. Young (Ed.), Affect in foreign language and second language learning: A practical guide to creating a low-anxiety classroom atmosphere, (pp. 2445). Boston: McGraw-Hill.

[34] North, S., \& Pillay, H. (2002). Homework: re-examining the routine. ELT journal, 56(2), 137-145.

[35] Piaget, J. (1966). Need and meaning of comparative studies in genetic psychology. International journal of Psychology, 1(1), 3-13.

[36] Piaget, J. (1972). Psychology and epistemology: Towards a theory of knowledge. Harmondsworth: Penguin.

[37] Reid, J. M. (1987). The learning style preferences of ESL students. TESOL Quarterly, 21, 87-111.

[38] Richterich, R. (1984). A European unit/ Credit system for modern language learning by adults. In J. Van Ek \& J. L. M. Trim, (Eds.). Across the threshold level. Pergamon.

[39] Robinson, P. (Ed.). (2002). Individual differences and instructed language learning. John Benjamins, Amsterdam.

[40] Robinson, P. (2003). Robinson, P. (2003). Attention and Memory during SLA. In C. J. Doughty \& H. Long (Eds.). The handbook of second language acquisition. Blackwell Publishing Ltd.

[41] Schmeck, R. R. (1981). Improving learning by improving thinking. Educational Leadership. (Feb. 1981, pp. 384-385).

[42] Skehan, P. (1989). Individual differences in second language learning. London: Edward Arnold.

[43] Thelen, H. (1954). Dynamics of groups at work. University of Chicago, Chicago, IL.

[44] Tomlinson, B. (Ed.). (2013). Developing materials for language teaching. London: Bloomsbury.

[45] Ushioda, E. (2013). Motivation and ELT: Global issues and local concerns. In E. Ushioda (Ed.). International perspectives on motivation. London: Palgrave Macmillan.

[46] Williams, M., \& Burden, R. L. (1997). Psychology for language teachers: A social constructivist approach. Cambridge: Cambridge University Press.

[47] Wong, L. L., \& Nunan, D. (2011). The learning styles and strategies of effective language learners. System, 39(2), 144-163.

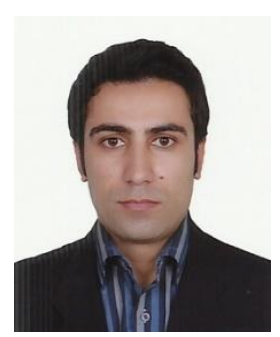

Hamed Abbasi Mojdehi is holding an M.A. degree in TEFL from Islamic Azad University, Rasht Branch, Iran.

He has more than 7 years of experience in Teaching English as a Foreign Language to Iranian young and adult students in intermediate level, advanced level, and IELTS preparatory courses. His fields of interest and research are mainly "EFL learners' individual differences", "IELTS preparatory courses", and "Psycholinguistics".

Mr. Mojdehi is currently working as an official IELTS instructor in various private institutes in Rasht, Iran.

E-mail: Haamed.Mojdehi@YAHOO.com

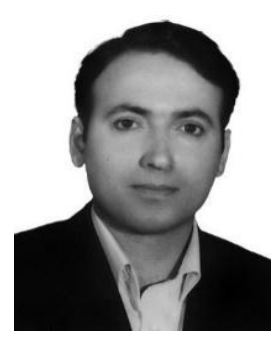

Davood Taghipour Bazargani is holding Ph.D degree in TEFL from Kharazmi University, Tehran, Iran.

He has more than twenty years of experience in Teaching English as a Foreign Language to Iranian university students and young learners in private institutes. His research interests are "Critical cultural awareness", "Critical pedagogy", "ESP", "Materials development", and "CDA".

Dr. Bazargani is currently an assistant professor of TEFL at Islamic Azad University, Rasht Branch, Iran.

E-mail: Bazargani74@YAHOO.com 